\title{
Lack of Association between Selenium Level and Human Epidermal Growth Factor Receptor 2 (AER2) Expression in Breast Cancer Tissue
}

Sanaz Salar Amoli (MSc)

Cancer Research Center,

Golestan University of Medical

Sciences, Gorgan, Iran

Sima Besharat (PhD)

Cancer Research Center,

Golestan University of Medical

Sciences, Gorgan, Iran

Amir Nader Emami Razavi (PhD)

Cancer Research Center,

Tehran University of Medical

Sciences, Tehran, Iran

Ali Asghar Ayatollahi (PhD)

Laboratory Sciences Research Center,

Golestan University of Medical

Sciences, Gorgan, Iran

Hamidreza Joshaghani (PhD)

Laboratory Sciences Research Center, Golestan University of Medical

Sciences, Gorgan, Iran

Corresponding Author: Hamidreza

Joshaghani

Tel: +989111779909

Email: hr_joshaghani@yahoo.com

Address: Golestan University of

Medical Sciences, Gorgan, Iran

Received: 18 Jan 2018

Revised: 29 Jan 2018

Accepted: 19 Jul 2018

\section{(c) (1) 8}

This work is licensed under a Creative

Commons Attribution 4.0 License.
ABSTRACT

Background and 0bjectives: Human epidermal growth factor receptor 2 (HER2) is a gene involved in development of breast cancer. Normally, HER2 receptors control breast cells growth and division. HER2 overexpression is the cause of almost $20 \%$ of all breast cancer incidents. The phosphoinositide 3 kinase (PI3K) pathway is important in the oncogenic function of HER2. It has been reported that compounds, such as selenium significantly attenuate oxidative stress-induced activation of the PI3K pathway, and can exert antitumor effects by downregulating PI3K activation. In this study, we evaluated association of selenium level and HER2 expression in breast cancer tissue.

Methods: Atomic absorption spectrometry and immunohistochemistry were used to evaluate selenium content and HER2 expression in 30 tissue sets (tumor and adjacent tissue) collected from 30 women diagnosed with breast cancer.

Results: HER2 was expressed in about 30\% of the samples. In HER2-positive tissues, mean level of selenium was $268.15 \mu \mathrm{g} / \mathrm{L}$ in tumors and $165.36 \mu \mathrm{g} / \mathrm{L}$ in tumor margins. In HER2-negative tissues, mean level of selenium was $206.43 \mu \mathrm{g} / \mathrm{L}$ in tumors and $184.39 \mu \mathrm{g} / \mathrm{L}$ in tumor margins. There was no significant association between selenium level and HER2 expression $(\mathrm{P}>0.05)$.

Conclusion: Based on the results, we conclude that there is no association between Se level and HER2 expression in breast cancer tissue.

Keywords: Selenium, HER2, Breast Neoplasms. 


\section{INTRODUCTION}

Breast cancer is the second leading cause of death among women (1). Human epidermal growth factor receptor 2 (HER2) gene amplification and/or protein (tyrosine kinase receptor) overexpression occur in many carcinomas, especially in breast cancer (2). HER2 overexpression also stimulates downstream signaling and promotes cell proliferation and survival. HER2 status is both a prognostic and a predictive factor for HER2targeted therapies. Therefore, it is necessary to accurately determine HER2 status in every breast cancer case (3).

Some dietary micronutrients, such as selenium (Se) are thought to have cancer protective and antioxidant effects (4). The potential role of Se in cancer prevention may be due to its effects on carcinogen metabolism, cellular immune response, cell proliferation, cell cycle, tumor cell invasion and estrogen and androgenreceptor expression (5). However, few epidemiological studies have investigated the relationship between dietary $\mathrm{Se}$ and breast cancer $(4,6-8)$. For decades, epidemiological and preclinical evidence supported the notion that higher dietary intake of Se decreases the incidence of cancers (9). However, the results of most animal studies indicate that the cancer preventive properties of Se occur at supranutritional levels. It is believed that active $\mathrm{Se}$ metabolite is a monomethylated $\mathrm{Se}$ species, such as methylselenol. In this study, we evaluated association of Se level and HER2 expression in breast cancer tissue.

\section{MATERIALS AND METHODS}

Sixty tissue samples (30 tumors and 30 tumor margins) were collected from 30 breast cancer patients in Imam Khomeini hospital in Tehran, Iran. A pathologist performed histopathological evaluations independently. Tumors containing tumor cells less than $50 \%$ of total cell mass as well as tumor margins containing any tumor cell were excluded from analysis. The tissue samples were stored at -80 ${ }^{\circ} \mathrm{C}$ until analysis. After the samples were cut and weighed $(0.02-0.03 \mathrm{~g})$, phosphate buffer saline (PBS, pH 7.2-7.4) was used to remove blood. The samples were frozen with liquid nitrogen and maintained at $2-8{ }^{\circ} \mathrm{C}$ after melting. Two hundred $\mu \mathrm{g} / \mathrm{L}$ of $0.2 \mathrm{M}$ PBS $(\mathrm{pH}$ 7.4) were added and the samples were homogenized by vortexing. Centrifugation was done at $13,000 \mathrm{rpm}$ for $20 \mathrm{~min}$ and the supernatant was removed. All Se measurement in both tissue fluid and serum were carried out in Kavosh Laboratory (Gorgan, Iran) using an atomic absorption spectrometer with longitudinally heated graphite atomizer (Agilent-AA240) and Zeeman background correction. In brief, $50 \mu \mathrm{L}$ of sample were diluted with $450 \mu \mathrm{L}$ of an aqueous solution of Triton, which was prepared by diluting $600 \mu \mathrm{L}$ Triton X-100, $5 \mathrm{mg}$ ascorbic acid and $2.5 \mathrm{ml}$ nitric acid in $500 \mathrm{ml}$ water. After diluting the samples and the calibration standard materials, $30 \mu \mathrm{L}$ of the diluted samples and $20 \mu \mathrm{L}$ of the freshly prepared matrix modifier $(500 \mathrm{mg} / \mathrm{L}$ palladium chloride) were injected into the furnace with an auto-sampler (VarianPSD120). Se hollow cathode lamp (Agilent Technologies) was also used for the analysis. HER 2 expression in breast cancer tissues was evaluated by immunohistochemistry tests. Chisquare test was performed using IBM SPSS Statistics (version 25) for data analysis.

\section{RESULTS}

About $30 \%$ of the samples were positive for HER2 expression. Mean level of $\mathrm{Se}$ in tumors and tumor margins of HER2positive tissues was $268.15 \mu \mathrm{g} / \mathrm{L}$ and 165.36 $\mu \mathrm{g} / \mathrm{L}$, respectively. Mean level of Se in tumors and tumor margins of HER2-negative tissues was $206.43 \mu \mathrm{g} / \mathrm{L}$ and $184.39 \mu \mathrm{g} / \mathrm{L}$, respectively. There was no significant association between Se level and HER2 expression in breast cancer tissues $(\mathrm{P}>0.05)$.

\section{DISCUSSION}

The association between Se intake and breast cancer incidence is still unclear. We found no association between Se level and HER2 expression in breast cancer tissues. In addition, there was no significant relationship between Se level and breast cancer.

Khandelwal et al. reported that Se is cytotoxic to triple negative (ER-/PR-/HER2-) breast cancer cell lines (10). In another study, Se could synergistically enhance the growthinhibitory effect of chemotherapeutic agents against triple negative breast cancer cells (11). It has been also claimed that $\mathrm{Se}$ can increase oxidative stress, stimulate growth-inhibitory effects, and induce apoptosis in triple negative breast cancer cell lines but not in nontumorigenic cells (12). It has been also suggested that organic Se supplementation 
may reduce/delay breast cancer metastasis (13). A study on Japanese women reported a significant difference in Se levels between newly diagnosed breast cancer patients and healthy counterparts (14), whereas other studies found no relationship between Se level and breast cancer risk or incidence (15-17).

\section{CONCLUSION}

Based on the results, we conclude that there is no association between Se level and

\section{REFERENCES}

1. Chen YC, Prabhu KS, Das A, Mastro AM. Dietary selenium supplementation modifies breast tumor growth and metastasis. Int J Cancer. 2013; 133(9): 2054-64. doi: $10.1002 / \mathrm{ijc} .28224$.

2. Huang HJ, Lee KJ, Yu HW, Chen CY, Hsu CH, Chen $\mathrm{HY}$, et al. Structure-based and ligand-based drug design for HER 2 receptor. J Biomol Struct Dyn. 2010; 28(1): 23-37.

3. Hou Y, Nitta H, Li Z. HER2 Gene Protein Assay Is Useful to Determine HER2 Status and Evaluate HER2 Heterogeneity in HER2 Equivocal Breast Cancer. Am J Clin Pathol. 2017; 147(1): 89-95. doi: 10.1093/ajcp/aqw211.

4. Dorgan JF, Sowell A, Swanson CA, Potischman N, Miller R, Schussler N, et al. Relationships of serum carotenoids, retinol, alpha-tocopherol, and selenium with breast cancer risk: results from a prospective study in Columbia, Missouri (United States). Cancer Causes Control. 1998; 9(1): 89-97.

5. Medina D. Mechanisms of selenium inhibition of tumorigenesis. J Am Coll Toxicol. 1986; 5: 21-7.

6. Burk RF. Selenium in Nutrition and Healthedited by PF Surai, 2006, 974 pages, hardcover, \$149. Nottingham University Press, Nottingham, United Kingdom. The American Journal of Clinical Nutrition. 2007; 86(1): 270.

7. Zeng H, Combs GF Jr. Selenium as an anticancer nutrient: roles in cell proliferation and tumor cell invasion. J Nutr Biochem. 2008; 19(1): 1-7.

8. Lee SO, Nadiminty N, Wu XX, Lou W, Dong Y, Ip C, et al. Selenium Disrupts Estrogen Signaling by Altering Estrogen Receptor Expression and Ligand Binding in Human Breast Cancer Cells. Cancer Research. 2005; 65(8): 3487-92.

9. Kim SJ, Uehara H, Karashima T, Mccarty M, Shih N, Fidler IJ. Expression of interleukin-8 correlates with angiogenesis, tumorigenicity, and metastasis of human prostate cancer cells implanted orthotopically in nude mice. Neoplasia. 2001; 3: 33-42.
HER2 expression in breast cancer tissue.

ACKNOWLEDGEMENTS

The authors would like to thank staff of Kavosh Laboratory, Tehran University Cancer Research Center and Golestan University of Medical Sciences.

\section{CONFLICT OF INTEREST}

The authors declare that there is no conflict of interest.

10. Khandelwal S, Gollahon L, Spallholz J, Boylan M, Garcia-Hernandez MDM. Abstract 4613: Cytotoxicity of selenium trastuzumab and bevacizumab immunoconjugates against triple negative breast cancer cells. Cancer Research. 2017; 77(13 Supplement): 4613.

11. Qi Y, Fu X, Xiong Z, Zhang H, Hill SM, Rowan BG, et al. Methylseleninic Acid Enhances Paclitaxel Efficacy for the Treatment of Triple-Negative Breast Cancer. PLoS ONE. 2012; 7(2): e31539. doi: 10.1371/journal.pone.0031539.

12. Guo CH, Hsia S, Shih MY, Hsieh FC, Chen PC. Effects of Selenium Yeast on Oxidative Stress, Growth Inhibition, and Apoptosis in Human Breast Cancer Cells. Int J Med Sci. 2015; 12(9): 748-58.

13. Chen YC, Prabhu KS, Das A, Mastro AM. Dietary selenium supplementation modifies breast tumor growth and metastasis. Int J Cancer. 2013; 133(9): 2054-64.

14. Schrauzer GN, Molenaar T, Mead S, Kuehn K, Yamamoto H, Araki E. Selenium in the blood of Japanese and American women with and without breast cancer and fibrocystic disease. Jpn J Cancer Res. 1985; 76: 374-7.

15. Dorgan JF, Sowell A, Swanson CA, Potischman N, Miller R, Schussler N, et al. Relationships of serum carotenoids, retinol, alpha-tocopherol, and selenium with breast cancer risk: results from a prospective study in Columbia, Missouri (United States). Cancer Causes Control. 1998; 9(1): 89-97.

16. van den Brandt PA1, Goldbohm RA, van't Veer P, Bode P, Dorant E, Hermus RJ, et al. Toenail selenium levels and the risk of breast cancer. Am J Epidemiol. 1994;140:20-6

17. van't Veer P, van der Wielen RP, Kok FJ, et al. Selenium in diet, blood, and toenails in relation to breast cancer: a case-control study. Am J Epidemiol. 1990; 131(6): 987-94. 